\title{
Summary of the Research on the Brand Building of Eurasian Economic Forum with Advancing Silk Road Economy New Starting Point Construction
}

\author{
Peng Zhang \\ Xi'an International University, Xi'an, Shaanxi, China, 710077
}

Keywords: Silk Road Economic Belt New Starting Point; Eurasian Economic Forum; Exhibition Brand; Comprehensive Review

\begin{abstract}
Since our country put forward the idea of "building the Silk Road Economic Zone", it has given the epoch-making development opportunities and richer construction connotations of Xi'an, and also brought challenges. Through the combing and analysis of the exhibition brand research literature and comprehensive review, it aims to lay the foundation for the brand building of Eurasian Economic Forum.
\end{abstract}

\section{Introduction}

With the increasingly fierce competition in the exhibition industry, most of the exhibition companies have recognized the urgency and importance of exhibition branding. Through the development of tangible brand building programs and specific development measures, not only help to enhance the brand exhibition image, competitiveness and influence, but also to promote the development of regional exhibition industry, improve the city's industrial structure, enhance the image of the city And competitive. This paper summarizes, analyzes and reviews the following documents by combing and analyzing domestic and foreign exhibition brand research:

\section{The Status of Domestic Research}

Exhibition Theory Research. Due to the rapid and good development of Chinese exhibition industry, domestic scholars are paying more and more attention to this emerging industry. At present, the domestic research results are mainly four aspects: the development of Chinese exhibition industry, the impact of exhibition industry on urban economy, related industry impact research and exhibition brand research. (2002) [1] in the "China Exhibition Economic Development Interpretation" in the exhibition economy research, clearly put forward the definition of exhibition economy, analysis of Chinese exhibition economy and development prospects of the situation, by comparing foreign success stories, proposed as a new industry in China how fast and healthy development. Chen Xinde [2] and so that the current exhibition industry market share is increasingly focused on the most valuable brand exhibition, the brand has become an important advantage of exhibition competition.

The Theory of Exhibition Brand. Liang He [3] that the Chinese exhibition industry in the development process is the lack of domestic and foreign markets generally recognized regional brands, the lack of a unified standard of exhibition services, the lack of high level of industry associations, faced with the international famous exhibition brand each break the risk. Based on the SWOT analysis of strategic management theory [4], this paper explores the strategic analysis of the exhibition brand of exhibition enterprises in Zhejiang Province, and then uses the strategic brand management method of Professor Keller to explore the idea of implementing the strategy of exhibition brand construction. Huajiang and Lou Jiajun [5] take the China East China Import and Export Fair as an example to sort out the three important stages of the creation of the China Fair brand, and use the part of the Analytic Hierarchy Process to analyze the exhibition center, 
management and management development environment three aspects of the brand to create a positive impact on the important factors. Chen Huiying [6] proposed the city exhibition brand by the strategic positioning, theme deduction, project planning, brand marketing, cultural highlight, emotional integration, government support, service management and hardware supporting nine elements. Lin Rui [7] that the activities of the exhibition can be integrated through a variety of ways to spread, to maximize the corporate brand, affecting the public awareness of the brand, emotion and attitude, establish a good image of the enterprise and brand in the community. Xu Lifang [8] proposed media organizations in the new media era has undergone fundamental changes, exhibition branding and transmission methods should be three-dimensional, multi-dimensional. In the new media era, we should profoundly explore the connotation of the exhibition brand, interact with the audience make full use of social media for marketing pay attention to the audience experience. Wang Dongqiang, Tian Shuqin, Yang Yu [9] that talent is the soul of the exhibition industry talent is the soul of the exhibition industry, but also to create the fundamental brand exhibition. With the development of the exhibition industry, the internationalization of the development of the exhibition industry, the brand exhibition needs high-quality exhibition professionals to build. Su Xia [10] that the fine, perfect service is to shape and enhance the image of the exhibition brand of security elements, service differentiation is becoming an important indicator of the core competitiveness of the exhibition.

\section{The Status Quo of Foreign Research}

Exhibition Theory Research. Foreign countries, especially Western developed countries on the relevant theory of exhibition time earlier, the current research work and

Related theory is more comprehensive, the reality of the development of the exhibition industry is the most mature, Germany, the United States, Italy,

Britain has become a famous exhibition industry development power. Among the works, the most famous is Chrisman (1991) [11] by the "trade fair show Daquan", the book on the exhibition preparation, operation and management have made a detailed explanation, he advocated the development of long-term goals As a guide, at each stage for different markets and then set up sub-goals, and with a variety of examples with the description, the scholars called the exhibition area of the classic.

Followed by Severt (2007) [12] "Motivation and behavioral awareness of organizers from local exhibitions" Analyze factors that affect exhibitions from the perspective of the organizers: Products and transactions are fundamental to the exhibition, and the convenience of participation quality, the impact of the audience's satisfaction, access to education is the main way to enhance the exhibition, the establishment of the relationship network is conducive to the exhibition to enhance the influence and activities and opportunities five factors; However Upchurch (2000) [13] (2007) [14] In the case of the decision-making influence of the organizers of the exhibition organizers, the influential factors of the organizers' Model "draws the conclusion that regional total consumption expenditure is the most important and influential factor.

Exhibition Brand Theory Research. American modern marketing master Philip Kotler [15] the definition and recognition of the brand so far is the most commonly cited by everyone. Aaker [16] has made a significant contribution to brand marketing theory and brand equity theory, among which the most influential is the "brand trilogy": "Managing Brand Assets" defines the definition and structure of brand equity, and explains how to use Brand equity to create value; "create a strong brand" mainly through real cases such as Saturn, the camera to explore the strong brand building process may encounter problems and what method to solve; "brand leadership" brand management to the leadership level, from company high-level decision-making brand building and management. These theories are highly influential in academia and become a model for academic and business study and study. This paper uses these theories as the basis for the study of exhibition branding, as a basis for creating structural equation model. Fredesion (2008) [17] argues that brand positioning is in line with market segmentation theory in marketing management, organizing market segmentation and selecting target consumers, as well as brand positioning, both for target market consumers the 
selection and satisfaction of a particular feature, the organization should focus on brand positioning process to carry out marketing management, develop marketing strategy. Brand positioning is the beginning of the brand is also the core of a link, the brand positioning if there is no precise grasp of the needs of target consumers, it has failed, behind the brand communication, brand maintenance even if no matter how good cannot play any role.

\section{The Literature Review}

Throughout the domestic and international related exhibition and exhibition brand theory research, mainly presents the following characteristics:

First, the research field of domestic and foreign scholars has been very broad, and there is a certain depth, and domestic research focused on the development of the exhibition industry, the exhibition industry on the impact of urban economy, the impact of related industries and other macro aspects, there are few theoretical studies on the microcosmic level of the elements of the exhibition (name, location, organizers and exhibitors, visitors, etc.) and the exhibition brand relationship;

Second, in the exhibition brand theory research, foreign developed countries on the exhibition brand modeling research has become mature, the theory of the formation of a more complete framework, but the branding theory applied to the exhibition of systematic research is not yet mature, but In the exhibition industry to discuss the necessity of the exhibition branding and the main countermeasures and methods, there is no micro-level in-depth study, did not form a systematic structural framework, and domestic research is still immature, lack of depth, quantitative analysis of the lack of still stay in Brand theory in the exhibition industry and the specific exhibition brand shaping the primary application stage.

By combing and analyzing the theory of exhibition and the theory of exhibition brand, we can get the domestic research on the shaping of the exhibition brand at present stage, and the lack of research on the branding of the exhibition brand.

\section{Acknowledgements}

Fund Project: Shaanxi Province social science sector 2017 major theoretical and practical issues research project; Project Name: A Study on the Branding of Eurasian Economic Forum Based on the New Starting Point of the Economic Development of Silk Road; Project Number: 2017Z144.

\section{References}

[1] Ma Yong. Interpretation of Chinese exhibition economy development[J]. Economic Geography, 2002 (5): 293-296

[2] Chen Xinde. Brand exhibition of the shaping and operation[J]. Business Research, 2007 (5): 179-182

[3] Liang He. World Expo exhibition effect study [J]. Science and Technology Management Research, 2009 (9): 79-81

[4] Huang Dan. Strategic management[M]. Beijing: Tsinghua University Press .2005

[5] Huagang, Lou Jiajun. Exhibition brand shaping factors influencing factors [J]. Tourism Forum, 2010 (2): 86-94

[6] Chen Huiying. Urban exhibition brand shaping and implementation of the path[J]. Journal of Wuhan University of Light Industry, 2015 (3): 102-106

[7] Lin Rui. On the exhibition of the brand image of the exhibition[J]. Art Technology, 2017 (10): 276 
[8] Xu Lifang.Study on the Branding and Transmission of Exhibition Brand in the New Media Era A Case Study of China and Strait Project Achievement Fair[J]. Journal of Nanjing Institute of Engineering (Social Science Edition), 2016 (12): 51-55 (in Chinese)

[9] Wang Dongqiang, Tian Shuqin, Yang Yu. China liquor professional exhibition exhibition brand shaping strategy $[\mathrm{J}]$.Enterprise, 2014 (1): 25-28

[10] Su Xia. Xi'an exhibition brand modeling strategy[J]. Management Manager, 2016 (10): 98

[11] Li Tiecheng, Liu Li. The new features and Journal of MICE in China[J].Economic Review, 2012 (7): 80-83

[12] Lawson F. Congress, Convention and Exhibition Facilities: Planning, Design and Management [M] .U.K .: Architectural Press Oxford, 2000. 28

[13] Brennan, K. Meetings in demand [J]. Lodging Hospitality, 2001, 57 (l): 41-43

[14] Leung M J. Central place theory and sport tourism Influence [J] .Annals of TourismResearch, 2007, 34 (2): 332-347.

[15] Philip Kotler, Marketing Management [M]. Beijing: Qinghua University Press. 2001.

[16] Aaker David and Kevin L. Keller. Consumer Evaluation; of Brand Extensions, Journal of Marketing, 1990 (54): 27-41

[17] Li Fei. Brand positioning point selection model research [J] Business economics and management, 2009, (11): 73-80 